\title{
XXII. An account of the remarkable accumulation of the exuviœ of bears, in a cave at Kühloch in Franconia
}

\section{Professor Buckland}

To cite this article: Professor Buckland (1823) XXII. An account of the remarkable accumulation of the exuviœ of bears, in a cave at Kühloch in Franconia , Philosophical Magazine, 62:304, 112-114, DOI: $10.1080 / 14786442308644389$

To link to this article: http://dx.doi.org/10.1080/14786442308644389

曲 Published online: 23 Jul 2009.

Submit your article to this journal $\sqsubset$

山 Article views: 2

Q View related articles ๘ 
XXII. An Account of the renarhable Accumulation of the Exurice of Bears, in a Cave at Kiüloch in Franconia. By Professor. BUCKLAND*.

THE cave of Kühloch (in Franconia), is more remarkable than all the rest, as being the only one I have ever seen, excepting that of Kirkdale, in which the animal remains have escaped disturbance by diluvial action; and the only one also in which I could find the black animal earth, said by other writers to occur so generally, and for which many of them appear to have mistaken the diluvial sediment in which the bones are so universally imbedded. The only thing at all like it, that I could find in any of the other caverns, were fragments of highly decayed bone, which occurred in the loose part of the diluvial sediment in the caves of Scharzfeld and Gailenreuth; but in the cave of Kühloch it is far otherwise. It is literally true that in this single cavern (the size and proportions of which are nearly equal to those of the interior of a large church) there are hundreds of cart loads of black animal dust entirely covering the whole floor, to a depth which must average at least six feet, and which, if we multiply this depth by the length and breadth of the cavern, will be found to exceed 5000 cubic feet. The whole of this mass has been again and again dug over in search of teeth and bones, which it still contains abundantly, though in broken fragments. The state of these is very different from that of the bones we find in any of the other caverns, being of a black, or, more properly speaking, dark umber colour throughout, and many of them readily crumbling under the finger into a soft dark powder, resembling mummy powder, and being of the same nature with the black earth in which they are imbedded. The quantity of animal matter accumulated on this floor is the most surprising, and the only thing of the kind I ever witnessed; and many hundred, I may say thousand, individuals must have contributed their remains to make up this appalling mass of the dust of death. It seems in great part to be derived from comminuted and pulverised bone; for the fleshy parts of animal bodies produce by their decomposition so small a quantity of permanent earthy residuum, that we must seek for the origin of this mass principally in decayed bones. The cave is so dry, that the black earth lies in the state of loose powder, and rises in dust under the

* This article is extracted from the section on the Caves in Franconia in Professor Buckland's "Reliquice Diluviana," lately published; of which interesting work, and soveral recent memoirs on subjects connected with those which are discussed in it, we purpose to give analyses in our next. 
feet: it also retains so large a proportion of its original animal matter, that it is occasionally used by the peasants as an enriching manure for the adjacent meadows".

The exterior of this cavern presents a lotty arch, in a nearly perpendicular cliff; which forms the left flank of the gorge of the Esbach, opposite the Castle of Rabenstein. The depth of the valley below it is less than 30 feet, whilst above it the hill rises rapidly, and sometimes precipitously, to 150 or 200 feet. This narrow valley or gorge is simply a valley of denudation, by which the waters of the Esbach fall into those of the Weissent. The breadth of the entrance arch is about 30 feet, its height 20 feet. As we advance inwards the cave increases in height and breadth, and near its inner extrenity divides into two large and lofty chambers, both of which terminate in a close round end, or cul de sac, at the distance of about 100 feet from the entrance. It is intersected by no fissures, and has no lateral communications connecting it with any other caverns, except one small hole close to its mouth, and which opens also to the valley. These circumstances are important, as they will assist to explain the peculiarly undisturbed state in which the interior of this cavern has remained, amid the diluvial changes that have affected so many others. The inclination of the floor, for about 30 feet nearest the mouth, is very considerable, and but little earth is lodged upon it; but further in, the interior of the cavern is entirely covered with a mass of dark brown or blackish earth, through which are disseminated in great abundance the bones and teeth of bears and other animals, and a few small fragments of limestone, which have probably fallen from the roof; but I could find no rolled pebbles. The upper portion of this earth seems to be mixed up with a quantity of calcareous loam, which, before it had been disturbed, by disging, probably formed a bed of diluvial sediment over the animal remains; but as we sink deeper, the earth gets blacker, and more free from loam, and seems wholly composed of decayed animal matter. There is no appearance of either stalactite or stalagmite having ever existed within this cavern.

In some of the particulars here enumerated, there is an apparent inconsistency with the phanomena of other caverns; but the differences are such as arise from the particular position

* I have stated, that the total quantity of animal matter that lies within this cavern cannot be computed at less than 5000 cubic feet. Now allowing two cubic feet of dust and bones for each individual animal, we shall have in this single vault the remains of at least 9500 bears, a number which may have been supplied in the space of 1000 ycars, hy a mortality at the rate of two and a half per annum.

Vol. 62. No. 304. Aug. 1823. 


\section{Prof. Buckland on the Exuvia of Bears at Kiihloch.}

and circumstances of the cave at Kühloch: the absence of pebbles, and the presence of such an enormous mass of animal dust, are the anomalies I allude to; and both these circumstances indicate a less powerful action of diluvial waters within this cave than in any other, excepting Kirkdale. To these waters, however, we must still refer the introduction of the brown loam, and the formation or laying open of the present mouth of the cavern; from its low position so near the bottom of the valley, this mouth could not have been exposed in its present state, and indeed must have been entirely covered under the solid rock, till all the materials that lay above it had been swept away, and the valley cut down nearly to its present base; and as the cave ends inwardly in a cul de sac, and there is no vertical fissure, or any other mode of access to it, but by the present mouth, if we can find therein any circumstances that would prevent the admission of pebbles from without, or the removal of the animal remains from within, the cause of the anomaly we are considering will be explained. The throat of the cave, by which we ascend from the mouth to the interior, is highly inclined upwards, so that neither would any pebbles that were drifting on with the waters that excavated the valley, ascend this inclined plane to enter the cave, nor would the external currents, however rapidly rushing by the outside of the mouth, have power to agitate (except by slight eddies in the lower part of the throat) the still waters that would fill the bottom of the cavern, and which being there quiescent, would, as at Kirkdale, deposit a sediment from the mud suspended in them upon the undisturbed remains of whatever kind that lay on the floor. From its low position, it is also probable that this vault formed the deepest recess of an extensive range of inhabited caves, to which successive generations of antediluvian bears withdrew themselves from the turbulent company of their fellows, as they felt sickness and death approaching; the habit of domesticated beasts and birds to retire and hide themselves on the approach of death, renders it probable that wild and savage animals also do the same. The unusual state of decay of the teeth and bones in this black earth may be attributed to the exposed state of this cavern arising from its large mouth and proximity to the external atmosphere, and to the absence of that protection which in closer and deeper caves they have received, by being secluded from such exposure, or imbedded in more argillaceous earth, or invested with and entirely sealed up beneath a crust of stalagmite. 